\title{
Sow performance in response to natural betaine fed during lactation and post- weaning during summer and non-summer months
}

\author{
S. M. Mendoza', R. D. Boyd ${ }^{1,2}$, J. Remus ${ }^{3}$, P. Wilcock ${ }^{4}$, G. E. Martinez ${ }^{1}$ and E. van Heugten ${ }^{1 *}$ (D)
}

\begin{abstract}
Background: Two studies were conducted to evaluate the effects of dietary natural betaine on sow reproductive performance during summer (Exp. 1) and non-summer months (Exp. 2). Treatments were designed as a $2 \times 2$ factorial arrangement with factors including dietary betaine $(0$ or $0.2 \%$ ) and period of supplementation (lactation or post-weaning until 35 days post-insemination). In Exp. 1, 322 and 327 sows and in Exp. 2, 300 and 327 sows representing young (parity 1 and 2) and mature (parity 3 to 6) sows, respectively, were used.

Results: In Exp. 1, supplementation of betaine during lactation increased sow body weight losses (- 11.95 vs. -14.63 $\mathrm{kg} ; P=0.024)$, reduced feed intake ( $4.12 \mathrm{vs} .4 .28 \mathrm{~kg} / \mathrm{d} ; P=0.052$ ), and tended to reduce percentage of no-value pigs $(P=0.071)$. Betaine fed post-weaning reduced weaning-to-estrus interval (5.75 vs. 6.68 days; $P=0.054)$ and farrowing rate $(86.74 \%$ vs. $91.36 \% ; P=0.060)$, regardless of parity group. Post-hoc analysis with sows clustered into 3 parity groups $(1,2$ and 3 , and $4+)$ indicated that betaine fed in lactation to parity $4+$ sows $(P=0.026)$ and betaine fed post-weaning to parity 1 sows increased the number of pigs born in the subsequent cycle $(P \leq 0.05)$. In Exp. 2 , betaine fed during lactation tended to reduce the weaning-to-estrus interval (6.64 vs. 7.50 days; $P=0.077)$ and farrowing rate ( $88.23 \%$ vs. 83.54\%; $P=0.089$ ), regardless of parity group. Feeding betaine post-weaning reduced number of pigs born ( $13.00 \mathrm{vs}$. $13.64 ; P=0.04)$ and pigs born alive (12.30 vs. $12.82 ; P=0.075)$, regardless of parity group.
\end{abstract}

Conclusions: Using $0.2 \%$ betaine during the non-summer months did not benefit sow performance. During the summer, betaine supplementation in lactation increased subsequent litter size in parity $4+$ sows. Betaine fed during the post-weaning period reduced the wean-to-estrus interval and farrowing rate, increased total number of pigs born for parity 1 sows and reduced total number of pigs born to parity 4+ sows. Further research is needed to determine if the detrimental effects on feed intake and farrowing rate may be correlated and depend on dietary betaine level.

Keywords: Betaine, Lactation, Post-weaning, Reproduction, Sows

\footnotetext{
* Correspondence: Eric vanHeugten@ncsu.edu

'Department of Animal Science, North Carolina State University, Raleigh, NC 27695, USA
}

Full list of author information is available at the end of the article

C C The Author(s). 2020 Open Access This article is licensed under a Creative Commons Attribution 4.0 International License, which permits use, sharing, adaptation, distribution and reproduction in any medium or format, as long as you give appropriate credit to the original author(s) and the source, provide a link to the Creative Commons licence, and indicate if changes were made. The images or other third party material in this article are included in the article's Creative Commons licence, unless indicated otherwise in a credit line to the material. If material is not included in the article's Creative Commons licence and your intended use is not permitted by statutory regulation or exceeds the permitted use, you will need to obtain permission directly from the copyright holder. To view a copy of this licence, visit http://creativecommons.org/licenses/by/4.0/. The Creative Commons Public Domain Dedication waiver (http://creativecommons.org/publicdomain/zero/1.0/) applies to the data made available in this article, unless otherwise stated in a credit line to the data. 


\section{Background}

Sow reproductive performance severely declines during the summer season. During the summer months sow non-productive days increase by 5 to 19 days [1] and this is mainly due to a delay in estrus, failure to return to estrus, or embryo losses after mating [2]. Farrowing rate has been reported to be $20 \%$ lower during the summer than sows bred during non-summer months [2]. In addition, total number of pigs born is estimated to be reduced by 0.05 piglets for each $1{ }^{\circ} \mathrm{C}$ above $20^{\circ} \mathrm{C}$ on the day of insemination [3]. Above $25^{\circ} \mathrm{C}$, sows decrease feed intake by $0.5 \mathrm{~kg} / \mathrm{d}$ per additional $1{ }^{\circ} \mathrm{C}$ [4] and increase tissue mobilization to sustain milk production [5]. Sows with poor feed intake during lactation continue the subsequent reproductive period with a negative energy balance [6], which acts as a negative feedback to prevent the onset of a new reproductive cycle.

Betaine, or tri-methyl glycine, is a methyl donor and osmoregulator that naturally accumulates in organisms that are adapted to saline or drought conditions [7, 8]. The role of betaine as an osmolyte has important implications because it can maintain cell volume and integrity under challenging conditions, including heat stress. Ramis et al. [9] fed betaine to sows during lactation and reported an improvement in litter gain. In addition, dietary betaine supplementation to lactating sows reduced the weaning to estrus interval [9-11] and increased subsequent litter size $[10,12]$. van Wettere et al. [13] reported that feeding betaine to gestating sows during the summer increased litter size, in particular, in mature sows. The effect of betaine supplementation to sows after weaning, during breeding, and early in gestation has not been evaluated previously. Betaine may be beneficial to the embryo during implantation as an osmoprotectant in the initial cellular division, as a methyl donor in the blastocyst $[14,15]$ and by reducing plasma homocysteine [16].

We hypothesize that the osmolyte betaine can alleviate the negative effects caused by high temperature in sows, by reducing the weaning to estrus interval, and increasing farrowing rate and subsequent litter size. The objective of the current study was to evaluate the impact of dietary betaine fed during lactation and post-weaning as a heat abatement strategy in sows exposed to heat stress.

\section{Material and methods}

Two studies were conducted in a commercial research facility in Oklahoma (2600 sows). Sows (Camborough, Pig Improvement Company (PIC), Hendersonville, TN) and piglets (TR-4 $\times$ Camborough product sows, PIC) used in these experiments were humanely treated following the practices outlined in the Guide for the Care and Use of Animals in Agricultural Research and Teaching [17]. Protocols were under the supervision of licensed veterinarians.
The two studies had the same experimental design and used the same diet formulations with the difference being the season that they were conducted. The design was a $2 \times 2$ factorial arrangement. Factors included dietary betaine (Vistabet ${ }^{\circ} 96$, AB Vista, Marlborough, UK) supplemented at 0 or $0.2 \%$ and 2 periods of supplementation (lactation or post-weaning until 35 days postinsemination). Dietary treatments were initiated immediately after farrowing and sows were fed lactation diets with either 0 or $0.2 \%$ betaine. After weaning, sows fed $0 \%$ betaine during lactation were either fed 0 or $0.2 \%$ betaine from weaning until 35 days post-breeding and, similarly, sows fed $0.2 \%$ betaine during lactation were fed either 0 or $0.2 \%$ betaine post-weaning until 35 days post-breeding. Diets were formulated to meet or exceed NRC [18] nutrient recommendations and manufactured by a commercial feed mill (Hanor Company, Enid, Oklahoma). Lactation diets (Table 1) were formulated to contain $3.31 \mathrm{~g}$ standardized ileal digestible (SID) lysine/Mcal ME, 0.56 SID methionine+cystine/lysine ratio, and $1.9 \mathrm{~g}$ of choline $/ \mathrm{kg}$ of diet. Diets for the post-weaning period were formulated to contain $1.82 \mathrm{~g}$ SID lysine/Mcal ME, 0.69 SID methionine+cystine/lysine ratio, and $1.15 \mathrm{~g}$ of choline $/ \mathrm{kg}$ of diet (Table 1). Diets were formulated to supply sufficient methyl donors to specifically evaluate the osmolyte properties of betaine. For both diets, the inclusion of betaine was made at the expense of corn. Diets were color-coded to visually confirm that proper diets were fed to the correct treatment groups. Feed samples were collected at the feed mill for every batch and every week at the farm to chemically verify the diets.

Proximate analysis (Table 2) of the diets was conducted by the Agricultural Experiment Station Chemical Laboratories, University of Missouri (Columbia, MO) using AOAC [19] procedures. Diets were analyzed for crude protein (Method 990.03), crude fat (Method 920.39a), crude fiber (Method 978.10), and ash (Method 942.05). Betaine concentrations of the diets were analyzed by the Bindley Bioscience Center at Purdue University (West Lafayette, IN) by liquid chromatography/mass spectrometry using an Agilent 1200 Rapid Resolution liquid chromatography system coupled to an Agilent 6460 series QQQ mass spectrometer (Agilent Technologies Inc., Santa Clara, CA).

For both experiments, sows were housed in the same farrowing rooms and the same breeding barn. Environmental temperatures in the farrowing rooms were set at $23.5^{\circ} \mathrm{C}$ at farrowing and gradually reduced to $21^{\circ} \mathrm{C}$ at weaning. Supplemental heat or cooling were provided using gas heaters and wet-cell cooling pads, respectively. Heat lamps were used to provide additional heat for piglets. In the gestation barn, environmental temperatures were set at $20^{\circ} \mathrm{C}$ year-around and temperature was managed using gas heaters and fans for ventilation. During the course of the experiments, ambient temperature and 
Table 1 Composition of the experimental diets, as fed basis ${ }^{a}$

\begin{tabular}{|c|c|c|}
\hline \multirow[t]{2}{*}{ Item } & \multicolumn{2}{|l|}{$\operatorname{Diet}^{b}$} \\
\hline & Lactation & Post-weaning \\
\hline \multicolumn{3}{|l|}{ Ingredient, \% } \\
\hline Corn, medium grind & 45.915 & 47.025 \\
\hline Soybean meal, 46.5\% CP & 32.1 & 4.0 \\
\hline Rice bran & 10 & 15 \\
\hline Wheat middlings & 6 & 30 \\
\hline Poultry fat & 2.35 & 0 \\
\hline Limestone & 1.12 & 1.45 \\
\hline Monocalcium phosphate, $21 \% \mathrm{P}$ & 0.985 & 0.870 \\
\hline Potassium, magnesium sulfate ${ }^{c}$ & 0.50 & 0.50 \\
\hline Salt & 0.40 & 0.40 \\
\hline Sow vitamin-mineral premix ${ }^{d}$ & 0.20 & 0.20 \\
\hline Choline chloride, $60 \%$ & 0.125 & 0.125 \\
\hline Anti-caking aid ${ }^{e}$ & 0.100 & 0.100 \\
\hline Organic mineral source $[\mathrm{Zn}-\mathrm{Mn}-\mathrm{Cu}]^{f}$ & 0.075 & 0.075 \\
\hline L-Lysine & 0.050 & 0.150 \\
\hline L-Threonine & 0.035 & 0.075 \\
\hline DL-Methionine & 0.015 & 0.000 \\
\hline Iron oxide ${ }^{g}$ & 0.030 & 0.030 \\
\hline \multicolumn{3}{|l|}{ Calculated nutrient composition } \\
\hline $\mathrm{ME}, \mathrm{Mcal} / \mathrm{kg}$ & 3.30 & 3.04 \\
\hline$C P, \%$ & 21.17 & 12.90 \\
\hline Lysine, \% & 1.17 & 0.64 \\
\hline Standardized ileal digestible Lys, \% & 1.05 & 0.56 \\
\hline Standardized ileal digestible Lys/ME, g/Mcal & 3.31 & 1.82 \\
\hline Standardized ileal digestible Met+Cys:Lys & 0.56 & 0.69 \\
\hline $\mathrm{Ca}, \%$ & 0.82 & 0.85 \\
\hline Available P, \% & 0.40 & 0.44 \\
\hline Choline, g/kg & 1.90 & 1.15 \\
\hline
\end{tabular}

${ }^{\mathrm{a}}$ Diets were formulated to exceed NRC (2012) requirements

${ }^{\text {b}}$ To create betaine added diets, natural betaine (Vistabet ${ }^{\oplus} 96$, AB Vista, Malborough, UK) was added at $0.2 \%$ at the expense of corn

'Dynamate (Mosaic, Plymouth, MN). Added as a laxative

dSupplied per kg of complete diet: vitamin A, 11,023 IU; vitamin $D_{3}, 1764 \mathrm{IU}$; vitamin E, $51 \mathrm{lU}$; vitamin $\mathrm{K}$, $4.4 \mathrm{mg}$; vitamin $\mathrm{B}_{12}, 0.044 \mathrm{mg}$; riboflavin, $8.8 \mathrm{mg}$; dpantothenate, $26.5 \mathrm{mg}$; niacin $55.1 \mathrm{mg}$; thiamine, $3.3 \mathrm{mg}$; pyridoxine, $3.3 \mathrm{mg}$; folic acid, $1.21 \mathrm{mg}$; biotin, $0.28 \mathrm{mg}$; $\mathrm{Zn}, 125 \mathrm{mg}$; Fe, $100 \mathrm{mg}$; Mn, $50 \mathrm{mg}$; $\mathrm{Cu}$, 25.0 mg; I, 0.7 mg; Se, 0.3 mg; phytase, 661 FTU (Phyzyme, Danisco A/S, Copenhagen, Denmark), and chromium, $0.4 \mathrm{mg} / \mathrm{kg}$

${ }^{\mathrm{e} D r y}$ anti-caking aid and non-nutritive carrier (KALLSIL, Kemin Industries, Inc., Des Moines, IA)

fSupplied per kg of complete diet: Zn, $50 \mathrm{mg}$ from $\mathrm{Zn}$ amino acid complex, $\mathrm{Mn}, 20 \mathrm{mg}$ from $\mathrm{Mn}$ amino acid complex, and $\mathrm{Cu}, 10 \mathrm{mg}$ from $\mathrm{Cu}$ amino acid complex (Availa, Zinpro Corporation, Eden Prairie, MN)

gused to color code diets. Diet with $0 \%$ betaine contained $\mathrm{Fe}_{3} \mathrm{O}_{4}$ (black) and diet with $0.2 \%$ betaine contained $\mathrm{Fe}_{2} \mathrm{O}_{3}$ (red)

humidity of the farrowing room and breeding barn were recorded using data recorders (logtag, MicroDAQ Ltd., Contoocook, NH, USA). Data recorders measured temperature and humidity every $5 \mathrm{~min}$. For the farrowing rooms, a data logger was placed for each farrowing group. For the breeding barn, two loggers were placed, one on each side of the barn. A heat index was calculated considering air temperature and relative humidity, according to the US National Weather Service.

Exp. 1

A total of 649 sows entered the farrowing room in groups of 20 to 26 sows. Within each group, sows were randomly assigned within parity groups to 1 of 4 treatments. The experimental design consisted of a generalized randomized complete block design and was balanced by parity. A total of 169,153 , and 327 sows representing parity 1 (P1), 2 (P2), and 3 to $6(\mathrm{P} 3+)$ were used in the study. Each group of sows aimed to contain $50 \%$ of young sows (P1 and P2) and $50 \%$ of mature sows (P3+). The first group entered the farrowing room in June and the last group $\left(30^{\text {th }}\right)$ was weaned in September. The first group was weaned in July and the last group was relocated to the gestation barn in November (day 35 post-insemination, end of dietary supplementation treatments).

Exp. 2

A total of 627 sows entered the farrowing room in groups of 22 to 24 . Within each group, sows were randomly assigned to 1 of 4 treatments considering parity groups. A total of 250, 50, and 327 sows representing P1, P2, and P3+ were used in the study. Each group of sows aimed to contain $50 \%$ of young sows (P1 and P2) and $50 \%$ of mature sows (P3+). The first group entered the farrowing room in February and the last group $\left(28^{\text {th }}\right)$ was weaned in June. The first group was weaned in March and the last group was relocated to the gestation barn in July (day 35 post-insemination, end of supplementation treatments).

\section{Lactation period}

Sows were weighed individually when they entered the farrowing room. In Exp. 1, sows entered the farrowing room on day $109 \pm 1$ and in Exp. 2 on day $112 \pm 2$ of gestation. Between placement and farrowing, sows were fed $1.82 \mathrm{~kg} / \mathrm{d}$ of a common lactation diet without betaine. After farrowing, dietary treatments were provided, and feed additions and feed refusals were recorded for each sow until weaning. Sows were fed to satiety and feed was offered at 08:00 $\mathrm{h}$ and 14:00 $\mathrm{h}$ to appetite, ensuring sows had some feed in front of them at all times. Number and weight of pigs at birth (alive, stillborn, and mummies) were recorded and placenta and weight of fluids were calculated from the equations reported by Walker and Young [20]. Litter birth weight, estimated placenta weight and estimated weight of fluids were subtracted from the weight of the sow at placement to estimate sow weight at farrowing. Sows were weighed for a second time on day 21 of lactation. The difference between sow 
Table 2 Analyzed nutrient composition of the experimental diets, as fed basis ${ }^{a}$

\begin{tabular}{|c|c|c|c|c|c|c|c|}
\hline \multirow[b]{2}{*}{ Diet } & \multirow[b]{2}{*}{ Experiment $^{b}$} & \multirow[b]{2}{*}{ Added betaine, \% } & \multicolumn{5}{|c|}{ Analyzed composition, \% } \\
\hline & & & $\mathrm{CP}$ & Crude fat & Crude fiber & Ash & Betaine \\
\hline Lactation & 1 & 0.0 & 22.09 & 5.68 & 3.10 & 7.16 & 0.057 \\
\hline Lactation & 1 & 0.2 & 19.34 & 4.82 & 3.28 & 6.20 & 0.197 \\
\hline Lactation & 2 & 0.0 & 21.66 & 5.86 & 3.08 & 6.91 & 0.055 \\
\hline Lactation & 2 & 0.2 & 21.25 & 6.01 & 3.20 & 6.89 & 0.347 \\
\hline Gestation & 1 & 0.0 & 12.51 & 5.00 & 4.19 & 7.16 & 0.287 \\
\hline Gestation & 1 & 0.2 & 12.81 & 5.42 & 4.13 & 6.96 & 0.489 \\
\hline Gestation & 2 & 0.0 & 13.23 & 4.93 & 4.36 & 6.65 & 0.265 \\
\hline Gestation & 2 & 0.2 & 13.26 & 5.37 & 4.27 & 6.75 & 0.508 \\
\hline
\end{tabular}

${ }^{a}$ Proximate analysis was conducted by the Agricultural Experiment Station Chemical Laboratories, University of Missouri, Columbia, MO, USA. Betaine was analyzed by the Bindley Bioscience Center at Purdue University, West Lafayette, IN, USA

${ }^{b}$ Exp. 1 was conducted during summer months and Exp. 2 was conducted during non-summer months

weight on day 21 and farrowing weight represented the body weight (BW) change (loss or gain) during lactation. Sow gain:feed was calculated as total gain during lactation (sow BW gain or loss plus total litter gain) divided by total feed intake during lactation.

Piglet cross-fostering was done 18 to $24 \mathrm{~h}$ after farrowing to allow for colostrum intake from their mothers. Cross-fostering was done within litters that were assigned to the same treatment. Litter size was standardized to 12 pigs. Handling, processing, and vaccination of piglets was performed according to the recommendations of licensed veterinarians and were identical for all litters. Litter weight gain was calculated as the difference between the weight of the litter on day 21 and the weight of the litter after cross-fostering (Exp. 1, $n=649$ litters; Exp. 2, subset $n=$ 352 litters). Date and weight of dead piglets were recorded. The piglets that did not reach $3.62 \mathrm{~kg}$ of BW on day 21 were considered no-value pigs. Pigs did not receive creep feed or milk replacer during the experiment. Piglets were weaned at the first opportunity after day 21 following the production schedule (lactation days $22 \pm 1$ in Exp. 1 and $23 \pm 1$ in Exp. 2).

Rectal temperature and respiration rate were measured on day 18 of lactation in a subset of sows $(n=44$ in Exp. 1 and $n=64$ in Exp. 2). Measurements were taken between $16: 00 \mathrm{~h}$ and 18:00 h. Rectal temperature was measured using a digital thermometer (M750 Series, GLA Agricultural Electronics, San Luis Obispo, CA, USA). Respiration rate was measured as the number of flank movements per $30 \mathrm{~s}$ and was reported on a per min basis.

\section{Post-weaning to 35 days post-insemination}

The breeding barn at the sow facilities is equipped with drop feeders (capacity of $3.62 \mathrm{~kg}$ ) and has two independent feeding systems. One-half of the barn received the $0 \%$ betaine and the other half the $0.2 \%$ betaine postweaning diets. After weaning, sows were distributed in the barn according to their assigned treatment and maintained until day 35 post insemination. Sows had ad libitum access to feed before signs of estrus were detected. At that point, sows were artificially inseminated and feed drops were adjusted to offer 1.8 to $2.7 \mathrm{~kg}$ of feed depending on sow body condition. Feed was delivered in two meals during the day. In Exp. 1 feed was delivered at 02:00 $\mathrm{h}$ and 08:00 $\mathrm{h}$, and in Exp. 2 feed was delivered at 09:00 $\mathrm{h}$ and 12:00 h. The schedule followed these recommendations to avoid high temperatures during the summer months at the time feed was provided.

Estrus detection and artificial insemination were performed following the standard operating procedures of the farm. Sows that did not return to estrus within 14 days discontinued the dietary treatments and were not used in the final analysis for subsequent litter size. After day 35 post-insemination, sows were moved to the gestation barn and were fed the standard gestation diet (control without betaine). Data collection during this period included days to estrus, the number of sows bred, the number of sows bred within 14 days after weaning, sows that farrowed, and sows that were culled. Once sows reached approximately day 110 of gestation, they were moved to the farrowing room and subsequent litter size at birth was recorded (pigs born alive, stillborn pigs, and mummies). Rectal temperature and respiration rate were measured on day 12 of gestation in a subset of sows ( $n=44$ in Exp. 1 and $n=64$ in Exp. 2) using the same procedures as described for the lactation period.

\section{Statistical analysis}

Sow and litter performance data were analyzed using the MIXED procedure of SAS (SAS Inst. Inc., Cary, NC). The model included the effect of betaine in lactation, parity group, and their interaction as fixed effects. The groups of sows (Exp. 1 groups = 30; Exp. 2 groups $=28$ ) that entered the farrowing room together were considered as the random effect. Rectal temperature and respiration rate were analyzed using the MIXED procedure 
of SAS (SAS Inst. Inc., Cary, NC). The model included the effect of betaine in lactation, parity group, and their interaction as fixed effects. The sow was considered as a random effect.

Subsequent reproductive performance data were analyzed using the MIXED procedure of SAS for days to estrus, total pigs born, pigs born alive, stillborn pigs and mummies. The GLM procedure of SAS was used for dichotomous variables. The model included the effect of betaine during lactation, the effect of betaine postweaning, parity group, and their interaction as fixed effects. Groups of sows were considered as a random effect for days to estrus, total pigs born, pigs born alive, stillborn pigs, and mummies. A post-hoc analysis was conducted for Exp. 1 to further separate the parity groups into parity 1 , parity 2 and 3, and parity 4, 5, and 6 to determine the impact of betaine within these parity groups, using similar models as previously described. Least squares means were reported, and differences were considered statistically significant at $P \leq 0.05$ and were considered tendencies when $0.05<P \leq 0.10$. The least significant difference method was used for single degree of contrast multiple comparisons.

\section{Results}

Chemical analysis of the diets was in reasonable agreement with calculated concentrations. Specifically for betaine, the concentration of betaine in control lactation diets averaged $0.056 \%$ and was $0.272 \%$ for the betaine supplemented diets, representing $0.216 \%$ additional betaine relative to the control diets. The concentration of betaine in the control gestation diets was $0.276 \%$ compared to $0.498 \%$ in the betaine supplemented diets, representing $0.222 \%$ added betaine.

\section{Exp. 1}

The average temperature of the farrowing room during the lactation period was $25.4 \pm 2.3^{\circ} \mathrm{C}$ (minimum of 16.4 and maximum of $35.7^{\circ} \mathrm{C}$ ) and relative humidity was $72.5 \% \pm 7.4 \%$ (minimum of $37.4 \%$ and maximum of $95.1 \%$ ), resulting in a heat index of $27.0 \pm 3.1^{\circ} \mathrm{C}$ (minimum of 17.8 and maximum of $41.2^{\circ} \mathrm{C}$ ). Sows were above an environmental temperature of $26^{\circ} \mathrm{C} 48.9 \%$ of the time and were above a heat index of $26^{\circ} \mathrm{C}$ for $62.3 \%$ of the time. The average temperature of the breeding barn (during the post-weaning until 35 days postinsemination) was $23.3 \pm 2.9^{\circ} \mathrm{C}$ (minimum of 16.8 and maximum of $31.2{ }^{\circ} \mathrm{C}$ ) and relative humidity was $72.1 \% \pm$ $8.6 \%$ (minimum of $40.9 \%$ and maximum of $93.2 \%$ ), with a calculated heat index of $24.9^{\circ} \mathrm{C}$ (minimum of 18.0 and maximum of $36.6{ }^{\circ} \mathrm{C}$ ). Sows were above an environmental temperature of $26^{\circ} \mathrm{C}$ for $19.1 \%$ of the time and above a heat index of $26^{\circ} \mathrm{C}$ for $28.0 \%$ of the time.
As expected, $\mathrm{P} 3+$ sows had greater BW at placement, after farrowing, and at day 21 of lactation $(P<0.001$; Table 3). Losses in BW during lactation were greater for $\mathrm{P} 1$ and $\mathrm{P} 2$ sows than $\mathrm{P} 3+$ sows $(P<0.001)$. Average daily feed intake and sow gain:feed were greater for P3+ sows $(P<0.004)$. Litter gain was greater for piglets from P3+ sows $(P<0.001)$, but no differences in the number of pigs weaned or mortality were observed due to parity group $(P \geq 0.385)$. Supplementation of betaine during the lactation period increased BW losses $(P=0.024)$ and this was related to lower feed intake $(P=0.052)$. No differences in litter gain $(P=0.350)$ or the number of pigs weaned were observed $(P=0.535)$ due to betaine supplementation. However, supplementation of betaine tended to reduce the percentage of no-value pigs $(P=0.071)$.

The average daily temperature of the farrowing room was $28.1{ }^{\circ} \mathrm{C}$ (range of 27.3 to $28.7^{\circ} \mathrm{C}$ ), humidity averaged $72.9 \%$ (range of $68.3 \%$ to $77.4 \%$ ) and the calculated heat index was $31.2^{\circ} \mathrm{C}$ (range of 30.0 to $32.5^{\circ} \mathrm{C}$ ) when rectal temperature and respiration rate were measured in a subset of sows. Sows were above an environmental temperature and heat index of $26^{\circ} \mathrm{C}$ for $100 \%$ of the time when measurements were taken during lactation. During the post-weaning period, environmental temperature was $27.2^{\circ} \mathrm{C}$ (range of 24.2 to $29.2^{\circ} \mathrm{C}$ ), humidity was $63.4 \%$ (range of $53.7 \%$ to $75 \%$ ), and the heat index was $28.7^{\circ} \mathrm{C}$ (range of 25.1 to $31.2^{\circ} \mathrm{C}$ ). Sows experienced an environmental temperature and heat index over $26^{\circ} \mathrm{C}$ for 91.3 and $94.5 \%$ of the time when respiration rate and rectal temperatures were measured. Betaine supplementation in lactation or post-weaning did not affect $(P \geq 0.091)$ rectal temperature or respiration rate (Table 4).

Following the lactation period, young sows (P1 and P2) tended to have greater weaning to estrus interval $(P=$ 0.068 ) than mature sows (P3+) (Table 5). Supplementation of betaine post-weaning tended to reduce $(P=0.054)$ the weaning to estrus interval. A greater number of P3+ sows were bred within 7 and 14 days after weaning (bred within 7 and 14 days:weaned) and overall (bred:weaned) ( $P \leq$ $0.037)$. Betaine supplementation post-weaning increased $(P=0.055)$ the number of sows bred within 7 days (bred within 7 days:weaned). Supplementation of betaine during lactation to P1 and P2 sows reduced the number of sows bred (bred:weaned), but did not affect P3+ sows (interaction, $P=0.004)$. Supplementation of betaine during lactation to P1 and P2 sows reduced the number of sows that returned to estrus after being bred (returns:bred within 14 days), but betaine during lactation to $\mathrm{P} 3+$ sows increased the number of sow that returned to estrus after being bred (interaction, $P=0.058$ ). Supplementation of betaine during the post-weaning period tended to reduce the number of sows that farrowed $(P=0.060)$ regardless of the parity group. More $\mathrm{P} 1$ and $\mathrm{P} 2$ sows tended $(P=0.098)$ to be sold as cull sows. 
Table 3 Effect betaine fed during lactation on sow and litter performance during the summer months (Exp. 1) $)^{a}$

\begin{tabular}{|c|c|c|c|c|c|c|c|}
\hline \multirow[b]{3}{*}{ Item } & \multicolumn{2}{|c|}{ Parity 1 and 2} & \multicolumn{2}{|c|}{ Parity 3+ } & \multirow[t]{3}{*}{ SEM } & \multicolumn{2}{|l|}{$P$-values ${ }^{b}$} \\
\hline & \multicolumn{4}{|c|}{ Betaine, \% } & & & \\
\hline & 0 & 0.2 & 0 & 0.2 & & Betaine & Parity group \\
\hline Sows, $n$ & 159 & 163 & 165 & 162 & & & \\
\hline BW at placement, $\mathrm{kg}^{\mathrm{C}}$ & 246.4 & 247.2 & 278.9 & 280.9 & 2.143 & 0.443 & $<0.001$ \\
\hline BW at farrowing, $\mathrm{kg}^{\mathrm{d}}$ & 227.1 & 227.3 & 257.7 & 257.5 & 1.966 & 0.983 & $<0.001$ \\
\hline BW at day $21, \mathrm{~kg}$ & 209.1 & 206.2 & 251.8 & 249.2 & 1.898 & 0.148 & $<0.001$ \\
\hline BW change, kg & -18.0 & -21.0 & -5.9 & -8.2 & 1.399 & 0.024 & $<0.001$ \\
\hline Sow BW gain, kg/d & -0.856 & -1.002 & -0.283 & -0.391 & 0.067 & 0.024 & $<0.001$ \\
\hline Lactation length, $d$ & 22.10 & 22.09 & 22.16 & 22.22 & 0.101 & 0.748 & 0.245 \\
\hline Feed intake, kg/d & 3.687 & 3.414 & 4.873 & 4.823 & 0.094 & 0.052 & $<0.001$ \\
\hline Sow gain:feed ${ }^{e}$ & 0.428 & 0.388 & 0.475 & 0.464 & 0.022 & 0.224 & 0.004 \\
\hline Litter weight after cross-fostering, $\mathrm{kg}^{\mathrm{f}}$ & 17.90 & 18.14 & 18.45 & 18.76 & 0.225 & 0.164 & 0.004 \\
\hline Litter weight on day $21, \mathrm{~kg}$ & 68.9 & 67.2 & 71.5 & 72.0 & 0.879 & 0.431 & $<0.001$ \\
\hline Litter gain, kg & 52.7 & 51.1 & 54.8 & 55.2 & 0.727 & 0.350 & $<0.001$ \\
\hline Pigs weaned per litter & 11.02 & 10.94 & 10.92 & 10.90 & 0.097 & 0.535 & 0.432 \\
\hline Piglet mortality, \% & 8.08 & 8.73 & 8.92 & 9.15 & 0.804 & 0.548 & 0.385 \\
\hline No-value pigs, $\%^{9}$ & 2.30 & 1.81 & 2.12 & 1.38 & 0.370 & 0.071 & 0.368 \\
\hline
\end{tabular}

${ }^{a}$ Values represent least squares means of $\mathrm{n}$ sows for sow and litter performance. The experiment was conducted from June to September

${ }^{b}$ The statistical analysis tested for main effects of betaine supplementation, parity group and their interaction. Group of placement (1 to 28$)$ was used as random effect. No significant interactions between parity group and betaine supplementation were detected $(P \geq 0.13)$

'Sow body weight (BW) was measured prior to sows entering the farrowing room (109 \pm 1 day of gestation)

${ }^{\mathrm{d}}$ Sow BW after farrowing was calculated using equations of Walker and Young [20]

eSow gain:feed was calculated as sow BW gain or loss plus total litter gain divided by total feed intake during lactation

fLitters were standardized to 12 pigs per litter

${ }^{9}$ No value pigs consisted of pigs weighing less than $3.62 \mathrm{~kg}$ at day 21 of lactation

Mature sows $(\mathrm{P} 3+)$ had a greater number of total pigs born, pigs born alive and stillborn pigs than P1 and P2 sows $(P \leq 0.026)$. A tendency for a three-factor interaction was observed for the total number of pigs born $(P=0.087)$ and pigs born alive $(P=0.057)$. For $\mathrm{P} 1$ and $\mathrm{P} 2$ sows, despite the fact that total pigs born and pigs born alive were not different among treatments, the greatest number of pigs were observed when sows received betaine during lactation and the lowest number of pigs when sows received betaine in both periods. For P3+ sows, despite the fact that total number of pigs born and pigs born alive were not different among treatments, the greatest number of pigs were observed when sows received betaine during lactation and the lowest number of pigs when sows received betaine during the post-weaning period.

An exploratory analysis was conducted to further separate the parity groups. Sows were clustered into three parity groups: parity 1 (P1), parity 2 and 3 (P2 and P3), and parity 4 or greater $(\mathrm{P} 4+)$ to determine effects of supplemental betaine (Table 6). For P1 sows, an interaction of betaine supplementation during lactation and betaine supplementation during the post-weaning period was observed for the number of total pigs born $(P=0.025)$ and pigs born alive $(P=0.007)$. Supplementation of betaine to $\mathrm{P} 1$ sows during the post-weaning period increased total number of pigs born and pigs born alive. However, supplementation of betaine during lactation and subsequently in the post-weaning period reduced total number of pigs born and pigs born alive. For P2 and P3 sows, betaine supplementation during lactation or the post-weaning period did not affect days to estrus, farrowing rate, total pigs born or pigs born alive. For P4+, supplementation of betaine during lactation increased the total number of pigs born $(P=0.026)$ and supplementation of betaine during the post-weaning period reduced the total number of pigs born $(P=0.014)$. Supplementation of betaine during the post-weaning period tended to reduce pigs born alive to P4+ sows $(P=0.084)$.

\section{Exp. 2}

The average temperature of the farrowing room during the lactation period was $23.1 \pm 2.7^{\circ} \mathrm{C}$ (minimum of 15.1 and maximum of $33.7^{\circ} \mathrm{C}$ ) and relative humidity was $59.3 \% \pm 13.5 \%$ (minimum of $2.7 \%$ and maximum of 95.2\%), resulting in a heat index of $25.1^{\circ} \mathrm{C}$ (minimum of 16.2 and maximum of $37.2^{\circ} \mathrm{C}$ ). Sows experienced an environmental temperature over $26^{\circ} \mathrm{C}$ for $16.3 \%$ of the time and a heat index of over $26^{\circ} \mathrm{C}$ for $20.6 \%$ of the time. The average temperature of the breeding barn (during the post-weaning period until 35 days post- 
Table 4 Effect of betaine supplementation during lactation and post-insemination on rectal temperature and respiration rate ${ }^{a}$

\begin{tabular}{|c|c|c|c|c|c|c|c|c|}
\hline \multirow[b]{3}{*}{ Item } & \multirow{2}{*}{\multicolumn{2}{|c|}{$\frac{\text { Parity } 1 \text { and } 2}{\text { Betaine, } \%}$}} & \multicolumn{2}{|c|}{ Parity 3+ } & \multirow[t]{3}{*}{ SEM } & \multicolumn{3}{|c|}{$P$-values ${ }^{b}$} \\
\hline & & & & & & \multirow[t]{2}{*}{ Betaine } & \multirow[t]{2}{*}{ Parity group } & \multirow[t]{2}{*}{ Interaction } \\
\hline & 0 & 0.2 & 0 & 0.2 & & & & \\
\hline \multicolumn{9}{|l|}{$\overline{\text { Summer }(\operatorname{Exp} .1)^{c}}$} \\
\hline \multicolumn{9}{|l|}{ Lactation } \\
\hline Rectal temperature, ${ }^{\circ} \mathrm{C}$ & 39.54 & 39.44 & 39.56 & 39.56 & 0.127 & 0.693 & 0.597 & 0.718 \\
\hline Respiration rate ${ }^{d}$ & 65.77 & 62.58 & 81.90 & 74.89 & 8.684 & 0.562 & 0.110 & 0.827 \\
\hline \multicolumn{9}{|l|}{ Post-insemination } \\
\hline Rectal temperature, ${ }^{\circ} \mathrm{C}$ & 38.53 & 38.49 & 38.46 & 38.53 & 0.076 & 0.825 & 0.851 & 0.470 \\
\hline Respiration rate ${ }^{d}$ & 22.00 & 18.58 & 13.20 & 12.33 & 2.031 & 0.399 & 0.005 & 0.614 \\
\hline \multicolumn{9}{|l|}{ Non-summer (Exp.2) } \\
\hline \multicolumn{9}{|l|}{ Lactation } \\
\hline Rectal temperature, ${ }^{\circ} \mathrm{C}$ & 39.41 & 39.43 & 39.19 & 39.25 & 0.138 & 0.772 & 0.154 & 0.889 \\
\hline Respiration rate ${ }^{d}$ & 76.25 & 66.80 & 67.47 & 76.24 & 5.636 & 0.952 & 0.954 & 0.112 \\
\hline \multicolumn{9}{|l|}{ Post-insemination } \\
\hline Rectal temperature, ${ }^{\circ} \mathrm{C}$ & 38.51 & 38.44 & 38.48 & 38.66 & 0.134 & 0.676 & 0.481 & 0.325 \\
\hline Respiration rate ${ }^{d}$ & 20.13 & 23.09 & 20.88 & 18.25 & 1.882 & 0.013 & $<0.001$ & 0.247 \\
\hline
\end{tabular}

${ }^{\mathrm{a}}$ For the lactation period, measurements were taken on day 18 of lactation between 16:00 and 18:00 $\mathrm{h}$. For the post-insemination period, measurements were taken on day 12 post-insemination between 16:00 and 18:00 $\mathrm{h}$

${ }^{\mathrm{b}}$ The statistical analysis tested for main effects of dietary betaine, parity group, and their interaction. Sow was used as random effect

'Each value represents the least squares mean of 11 sows ( 44 sows total). For the lactation period, the average temperature, humidity, and heat index of the farrowing room were $28.1^{\circ} \mathrm{C}$ (range of 27.3 to $28.7^{\circ} \mathrm{C}$ ), $72.9 \%$ (range of $68.3 \%$ to $77.4 \%$ ) and $31.2^{\circ} \mathrm{C}$ (range of 30.0 to $32.5^{\circ} \mathrm{C}$ ), respectively. Sows were above an environmental temperature and heat index of $26^{\circ} \mathrm{C}$ for $100 \%$ of the time when measurements were taken. During the post-weaning period, environmental temperature, humidity, and heat index were $27.2^{\circ} \mathrm{C}$ (range of 24.2 to $29.2^{\circ} \mathrm{C}$ ), $63.4 \%$ (range of $53.7 \%$ to $75 \%$ ), and $28.7^{\circ} \mathrm{C}$ (range of 25.1 to $31.2^{\circ} \mathrm{C}$ ), respectively. Sows experienced an environmental temperature and heat index over $26^{\circ} \mathrm{C}$ for $91.3 \%$ and $94.5 \%$ of the time

${ }^{\mathrm{d}}$ Respiration rate was measured as the number of flank movements per min

${ }^{e}$ Each value represents the least squares mean of 16 sows (64 sows total). For the lactation period, average temperature, humidity, and heat index of the farrowing room were $26.8^{\circ} \mathrm{C}$ (range of 22.8 to $29.7^{\circ} \mathrm{C}$ ), $61.8 \%$ (range of $47.2 \%$ to $78.4 \%$ ), and $28.2^{\circ} \mathrm{C}$ (range of 24.4 to $32.7^{\circ} \mathrm{C}$ ), respectively. Sows were above an environmental temperature and heat index of $26^{\circ} \mathrm{C}$ for $72.0 \%$ and $83.7 \%$ of the time. During the post-weaning period, the average temperature, humidity, and heat index of the breeding barn were $24.6^{\circ} \mathrm{C}$ (range of 22.9 to $27.2^{\circ} \mathrm{C}$ ), $67.7 \%$ (range of $49.7 \%$ to $79.8 \%$ ), and $26.0^{\circ} \mathrm{C}$ (range of 23.8 to $29.4^{\circ} \mathrm{C}$ ). Sows experience environmental temperatures and a heat index of over $26^{\circ} \mathrm{C}$ for $22.2 \%$ and $38.9 \%$ of the time, respectively

insemination) was $23.9 \pm 2.0^{\circ} \mathrm{C}$ (minimum of 17.4 and maximum of $33.5^{\circ} \mathrm{C}$ ) and humidity was $69.9 \% \pm 12.3 \%$ (minimum was $8.4 \%$ and maximum was $93.5 \%$ ). The heat index averaged $25.1{ }^{\circ} \mathrm{C}$ (minimum of 18.3 and maximum of $41.7^{\circ} \mathrm{C}$ ). Sows were above an environmental temperature of $26^{\circ} \mathrm{C}$ for $15.2 \%$ of the time and above a heat index of $26^{\circ} \mathrm{C}$ for $21.1 \%$ of the time.

Mature sows $(\mathrm{P} 3+)$ had greater $(P<0.001) \mathrm{BW}$ at placement, after farrowing, and at day 21 of lactation (Table 7). During the lactation period, $\mathrm{P} 3+$ sows gained $\mathrm{BW}$, while P1 and P2 sows had BW losses $(P<0.001)$. Average daily feed intake and sow gain:feed were greater for $\mathrm{P} 3+$ sows $(P<0.001)$. Litter gain was greater for $\mathrm{P} 3+$ sows $(P<$ $0.001)$, but there were no differences in the number of pigs weaned or piglet mortality due to parity group $(P \geq 0.816)$. Supplementation of betaine during the lactation period did not affect sow or litter performance $(P \geq 0.155)$.

The average daily temperature of the farrowing room was and $26.8 \pm 1.5^{\circ} \mathrm{C}$ (range of 22.8 to $29.7^{\circ} \mathrm{C}$ ), humidity was $61.8 \%$ (range of $47.2 \%$ to $78.4 \%$, and heat index of $28.2{ }^{\circ} \mathrm{C}$ (range of 24.4 to $32.7^{\circ} \mathrm{C}$ ) when rectal temperature and respiration rate were measured in the subset of sows. Sows were above an environmental temperature and heat index of $26^{\circ} \mathrm{C}$ for 72.0 and $83.7 \%$ of the time. During the post-weaning period, the average temperature of the breeding barn was $24.6^{\circ} \mathrm{C}$ (range of 22.9 to $27.2^{\circ} \mathrm{C}$ ), humidity was $67.7 \%$ (range of $49.7 \%$ to $79.8 \%$ ), and heat index was $26.0^{\circ} \mathrm{C}$ (range of 23.8 to $29.4^{\circ} \mathrm{C}$ ). Sows experience environmental temperatures and a heat index of over $26^{\circ} \mathrm{C}$ for $22.2 \%$ and $38.9 \%$ of the time, respectively. Betaine supplementation in lactation did not affect $(P \geq 0.772)$ rectal temperature or respiration rate, but respiration rate was decreased $(P=0.013)$ when betaine was supplemented post-insemination (Table 4).

A tendency for a three-factor interaction was observed for days to estrus $(P=0.09)$ (Table 8). Supplementation of betaine only during the post-weaning period increased the numbers of days to estrus in P1 and P2 sows compared to P1 and P2 sows fed betaine in both periods (lactation and post-weaning) without impacting P3+ sows. As an overall effect, betaine supplementation during lactation tended to reduce days to estrus $(P=0.077)$. Supplementation of betaine during the post-weaning period to P1 and P2 sows reduced the number of sows 
Table 5 Effect of betaine supplementation on subsequent reproductive performance of sows during the summer months (Exp. 1) ${ }^{d}$

\begin{tabular}{|c|c|c|c|c|c|c|c|c|c|c|c|c|}
\hline \multirow[b]{5}{*}{ Item } & \multicolumn{4}{|c|}{ Parity 1 and 2} & \multicolumn{4}{|l|}{ Parity $3+$} & \multirow[t]{5}{*}{ SEM } & \multirow{2}{*}{\multicolumn{3}{|c|}{$P$-values ${ }^{\mathrm{e}}$}} \\
\hline & \multicolumn{8}{|c|}{ Betaine in lactation diets, \% } & & & & \\
\hline & 0 & 0 & 0.2 & 0.2 & 0 & 0 & 0.2 & 0.2 & & \multirow{3}{*}{$\begin{array}{l}\text { Parity } \\
\text { group }\end{array}$} & \multirow{3}{*}{$\begin{array}{l}\text { Betaine } \\
\text { lactation }\end{array}$} & \multirow{3}{*}{$\begin{array}{l}\text { Betaine } \\
\text { post- weaning }\end{array}$} \\
\hline & \multicolumn{8}{|c|}{ Betaine in post-weaning diets, $\%$} & & & & \\
\hline & 0 & 0.2 & 0 & 0.2 & 0 & 0.2 & 0 & 0.2 & & & & \\
\hline Sows, $n$ & 76 & 83 & 83 & 80 & 85 & 80 & 80 & 82 & & & & \\
\hline Days to estrus & 6.73 & 6.17 & 7.94 & 5.79 & 5.82 & 5.64 & 6.24 & 5.43 & 0.674 & 0.068 & 0.587 & 0.054 \\
\hline Bred within 7 days:weaned & 0.842 & 0.916 & 0.783 & 0.850 & 0.894 & 0.913 & 0.888 & 0.927 & 0.036 & 0.026 & 0.256 & 0.055 \\
\hline Bred within 14 days:weaned & 0.868 & 0.928 & 0.807 & 0.863 & 0.918 & 0.913 & 0.900 & 0.939 & 0.034 & 0.037 & 0.227 & 0.127 \\
\hline Overall bred:weaned ${ }^{f}$ & 0.974 & 1.000 & 0.940 & 0.913 & 0.988 & 0.975 & 1.000 & 0.988 & 0.018 & 0.015 & 0.059 & 0.606 \\
\hline Returns:bred within 14 days $^{9}$ & 0.136 & 0.169 & 0.119 & 0.087 & 0.038 & 0.123 & 0.097 & 0.169 & 0.038 & 0.434 & 0.959 & 0.145 \\
\hline Farrowed:weaned ${ }^{\text {h }}$ & 0.921 & 0.880 & 0.855 & 0.825 & 0.953 & 0.875 & 0.925 & 0.890 & 0.035 & 0.098 & 0.175 & 0.060 \\
\hline Cull:weaned & 0.053 & 0.108 & 0.072 & 0.138 & 0.047 & 0.075 & 0.063 & 0.049 & 0.029 & 0.098 & 0.648 & 0.104 \\
\hline Total pigs born ${ }^{i}$ & $12.55^{\mathrm{b}}$ & $13.33^{\mathrm{a}, \mathrm{b}}$ & $13.39^{a, b}$ & $12.35^{b}$ & $14.17^{\mathrm{a}}$ & $13.30^{\mathrm{a}, \mathrm{b}}$ & $14.46^{\mathrm{a}}$ & $14.00^{\mathrm{a}}$ & 0.462 & 0.001 & 0.511 & 0.224 \\
\hline Pigs born alivej & $11.94^{\mathrm{b}, \mathrm{c}}$ & $12.75^{a, b, c}$ & $12.84^{\mathrm{ab}}$ & $11.56^{c}$ & $13.05^{a, b}$ & $12.59^{a, b, c}$ & $13.20^{\mathrm{a}}$ & $13.00^{a, b}$ & 0.439 & 0.026 & 0.827 & 0.367 \\
\hline Stillborn pigs ${ }^{k}$ & 0.62 & 0.58 & 0.55 & 0.79 & 1.11 & 0.71 & 1.27 & 1.00 & 0.160 & 0.001 & 0.196 & 0.286 \\
\hline Mummies & 0.129 & 0.172 & 0.159 & 0.180 & 0.117 & 0.129 & 0.214 & 0.164 & 0.061 & 0.927 & 0.327 & 0.880 \\
\hline
\end{tabular}

$\overline{a, b, c}$ Means with different superscripts differ $(P \leq 0.05)$

${ }^{d}$ Values represent least squares means of $n$ sows

'The statistical analysis tested for main effects of betaine supplementation during lactation, post-weaning, or both, parity group and their interactions. The group

of placement ( 1 to 30 ) was used as the random effect in the analysis of days to estrus, total pigs born, pigs born alive, stillborn pigs, and mummies

f Lactation and parity group interaction $(P=0.004)$

${ }^{9}$ Lactation and parity group interaction $(P=0.058)$

${ }^{h}$ Sows that were weaned and farrowed regardless of the day that were bred

'Three factor interaction $(P=0.087)$

${ }^{j}$ Three factor interaction $(P=0.057)$

${ }^{\mathrm{k}}$ Post-weaning and parity group interaction $(P=0.051)$

bred (bred:weaned) (interaction, $P=0.079$ ), but did not affect P3+ sows.

A greater number of P3+ sows returned to estrus $(P=0.008)$ after being bred (returns:bred with 14 days) compared to P1 and P2 sows. In addition, supplementation of betaine during lactation to $\mathrm{P} 3+$ sows increased the number of sows that returned to estrus after first insemination (returns:bred within 14 days; interaction, $P=0.040$ ), but did not affect P1 and P2 sows. Supplementation of betaine during lactation to P3+ sows reduced the number of sows that farrowed (interaction, $P=0.047$ ), but did not affect P1 and P2 sows. The cull rate tended to be higher for $\mathrm{P} 1$ and P2 sows $(P=0.069)$ compared to $\mathrm{P} 3+$ sows. However, among $\mathrm{P} 3+$ sows, the group that received betaine during lactation had a higher cull rate (interaction, $P=0.108)$.

Mature sows $(\mathrm{P} 3+)$ had a greater number of total pigs born, pigs born alive, stillborn pigs $(P \leq 0.001)$, and tended to have more mummies $(P=0.073)$ compared to P1 and P2 sows. Supplementation of betaine in the post-weaning period reduced total number of pigs born $(P=0.040)$ and tended to reduce pigs born alive $(P=0.075)$ and mummies $(P=0.054)$, regardless of parity group.

\section{Discussion}

Dietary supplementation of betaine has been shown to improve the subsequent reproductive performance of sows when fed during lactation $[9,10]$ and gestation [13] in the summer months. In the present studies, we evaluated betaine supplementation during lactation and the post-weaning until day 35 post-insemination period to determine the optimum time frame for betaine supplementation. In addition, we evaluated which parity of sows were more responsive to betaine supplementation, based on previous data that suggested that mature sows had a greater response than young sows [12]. Two studies were conducted, one during the summer months and one during non-summer months to determine if the effect of betaine was more pronounced during the summer season or could also be detected during the nonsummer season.

The diets in the present studies were formulated to provide enough choline, methionine, and folic acid to supply sufficient quantities of methyl donors in order to specifically determine the impact of the osmolyte properties of betaine. The choline requirement for lactating sows is $5.25 \mathrm{~g} / \mathrm{d}$ and for gestating sows is $2.3 \mathrm{~g} / \mathrm{d}$ [18]. During the lactation period, sows were provided with $8.74 \mathrm{~g} / \mathrm{d}$ of choline and during the post-weaning period 
Table 6 Exploratory analysis of dietary betaine on subsequent reproductive performance during summer months (Exp. 1) ${ }^{c}$

\begin{tabular}{|c|c|c|c|c|c|c|c|c|}
\hline \multirow[t]{4}{*}{ Item } & \multicolumn{4}{|c|}{ Betaine in lactation diets, \% } & \multirow[t]{4}{*}{ SEM } & \multicolumn{3}{|l|}{$P$-values ${ }^{d}$} \\
\hline & 0 & 0 & 0.2 & 0.2 & & \multirow{3}{*}{$\begin{array}{l}\text { Betaine } \\
\text { lactation }\end{array}$} & \multirow{3}{*}{$\begin{array}{l}\text { Betaine } \\
\text { post- } \\
\text { weaning }\end{array}$} & \multirow[t]{3}{*}{ Interaction } \\
\hline & \multicolumn{4}{|c|}{ Betaine in post-weaning diets, $\%$} & & & & \\
\hline & 0 & 0.2 & 0 & 0.2 & & & & \\
\hline Parity $1, n$ & 39 & 44 & 44 & 42 & & & & \\
\hline Days to estrus & 5.78 & 6.82 & 7.80 & 5.19 & 0.960 & 0.843 & 0.415 & 0.061 \\
\hline Farrowed:weaned ${ }^{e}$ & 0.923 & 0.841 & 0.818 & 0.833 & 0.054 & 0.327 & 0.555 & 0.328 \\
\hline Total pigs born & $12.32^{a, b}$ & $13.82^{\mathrm{a}}$ & $13.40^{\mathrm{a}, \mathrm{b}}$ & $12.18^{\mathrm{b}}$ & 0.598 & 0.638 & 0.821 & 0.025 \\
\hline Pigs born alive & $11.61^{b}$ & $13.33^{\mathrm{a}}$ & $12.93^{\mathrm{a}, \mathrm{b}}$ & $11.38^{\mathrm{b}}$ & 0.598 & 0.599 & 0.888 & 0.007 \\
\hline Parity 2 and $3, n$ & 71 & 71 & 71 & 72 & & & & \\
\hline Days to estrus & 7.21 & 5.69 & 7.16 & 6.66 & 0.815 & 0.569 & 0.216 & 0.526 \\
\hline Farrowed:weaned & 0.929 & 0.915 & 0.915 & 0.847 & 0.035 & 0.245 & 0.245 & 0.444 \\
\hline Total pigs born & 13.42 & 13.20 & 13.41 & 13.01 & 0.541 & 0.848 & 0.550 & 0.864 \\
\hline Pigs born alive & 12.58 & 12.56 & 12.85 & 12.25 & 0.515 & 0.969 & 0.521 & 0.540 \\
\hline Parity 4,5 and $6, n$ & 51 & 48 & 48 & 48 & & & & \\
\hline Days to estrus & 5.28 & 5.56 & 6.25 & 4.51 & 0.685 & 0.957 & 0.242 & 0.107 \\
\hline Farrowed:weaned ${ }^{e}$ & 0.961 & 0.854 & 0.916 & 0.896 & 0.041 & 0.977 & 0.127 & 0.303 \\
\hline Total pigs born & 14.15 & 12.90 & 15.37 & 14.02 & 0.585 & 0.026 & 0.014 & 0.927 \\
\hline Pigs born alive & 13.07 & 12.06 & 13.59 & 12.88 & 0.552 & 0.178 & 0.084 & 0.768 \\
\hline
\end{tabular}

a,b Means with different superscripts differ $(P \leq 0.05)$

Calues represent least squares means of $n$ sows

${ }^{\mathrm{d}}$ The statistical analysis tested for main effects of betaine supplementation during lactation and/or post-weaning, and their interaction. The group of placement ( 1 to 30) was used as the random effect in the analysis of total pigs born and pigs born alive

${ }^{\text {e}}$ Sows that were weaned and farrowed regardless of the day that were bred

with $2.5 \mathrm{~g} / \mathrm{d}$ of choline. Methionine requirements for lactating and gestating sows are $0.22 \%$ and $0.12 \%$ of standardized ileal digestible (SID) methionine, respectively [18]. Diets in the present studies were formulated to provide $0.28 \%$ and $0.18 \%$ of SID methionine, respectively. The concentration of betaine evaluated in the present experiments were based on Campbell and Virtanen [12], who reported that betaine supplementation at $0.2 \%$ to diets meeting all nutrient requirements increased the number of pigs in the subsequent cycle by 1 pig, whereas betaine supplemented at $0.4 \%$ reduced sow feed intake.

The analyzed concentrations of betaine in the experimental diets showed an average of $0.216 \%$ and $0.222 \%$ additional betaine in supplemented lactation and gestation diets, respectively, which is consistent with the target of $0.20 \%$ supplemental betaine. Betaine concentrations were higher in the gestation diets compared to the lactation diets because of higher endogenous concentrations of betaine in the control gestation diet, which is likely related to the relatively high concentration of betaine in wheat middlings compared to very low levels in corn [21].

Exp. 1 was conducted during the summer months. The average temperature in the farrowing room was $2.3^{\circ} \mathrm{C}$ greater and humidity was $13.2 \%$ greater than the respective averages recorded in the non-summer experiment. Moreover, sows experienced a temperature of $26^{\circ} \mathrm{C}$ or greater
$48.9 \%$ (62.3\% for heat index) of the time during the lactation period in the summer compared to $16.3 \%$ (20.6\% for heat index) in the non-summer experiment, indicating significant exposure to heat stress. During the breeding period, environmental temperatures and humidity were relatively similar when evaluating averages and sows experienced slightly more time exposed to temperatures over $26^{\circ} \mathrm{C}$ during the summer $(19.1 \%$ and $28.0 \%$ for temperature and heat index, respectively) compared to the non-summer months (16.3\% and $21.1 \%$ for temperature and heat index, respectively). The temperature exposure differences in the summer compared to non-summer, especially in lactation, are practically relevant and consistent with other studies evaluating the impact of betaine in sows during heat stress. In spite of these differences in heat exposure, respiration rate and rectal temperatures were not markedly different between the summer and non-summer months.

In the summer experiment, sows were $13 \mathrm{~kg}$ heavier when entering the farrowing rooms than the sows in the non-summer experiment. Nonetheless, BW on day 21 was similar in both experiments. Therefore, BW losses were greater in the summer experiment, which was associated with a reduction in feed intake of $14 \%$. Surprisingly, in the summer experiment, litter gain was $13 \%$ greater and sows weaned 0.2 more pigs compared to the non-summer experiment. 
Table 7 Effect of betaine fed during lactation on sow and litter performance during non-summer months (Exp. 2) ${ }^{a}$

\begin{tabular}{|c|c|c|c|c|c|c|c|}
\hline \multirow[t]{3}{*}{ Item } & \multicolumn{2}{|c|}{ Parity 1 and 2} & \multicolumn{2}{|c|}{ Parity $3+$} & \multirow[t]{3}{*}{ SEM } & \multicolumn{2}{|c|}{$P$-values ${ }^{b}$} \\
\hline & \multicolumn{4}{|c|}{ Betaine, \% } & & \multirow[b]{2}{*}{ Betaine } & \multirow[b]{2}{*}{ Parity group } \\
\hline & 0 & 0.2 & 0 & 0.2 & & & \\
\hline Sows, $n$ & 150 & 150 & 163 & 164 & & & \\
\hline BW at placement, $\mathrm{kg}^{\mathrm{c}}$ & 225.8 & 223.6 & 276.7 & 275.7 & 2.337 & 0.469 & $<0.001$ \\
\hline BW at farrowing, $\mathrm{kg}^{\mathrm{d}}$ & 206.4 & 204.5 & 252.3 & 252.4 & 2.289 & 0.666 & $<0.001$ \\
\hline BW at day $21, \mathrm{~kg}$ & 199.5 & 196.5 & 255.0 & 254.2 & 2.245 & 0.348 & $<0.001$ \\
\hline BW change, kg & -7.1 & -7.9 & 2.0 & 1.8 & 1.428 & 0.698 & $<0.001$ \\
\hline Sow BW gain, kg/d & -0.340 & -0.376 & 0.096 & 0.087 & 0.068 & 0.698 & $<0.001$ \\
\hline Lactation length, d & 22.96 & 23.18 & 23.16 & 23.27 & 0.113 & 0.075 & 0.110 \\
\hline Feed intake, kg/d & 4.31 & 4.24 & 5.61 & 5.47 & 0.101 & 0.155 & $<0.001$ \\
\hline Sow gain:feed ${ }^{e}$ & 0.412 & 0.401 & 0.444 & 0.486 & 0.015 & 0.203 & $<0.001$ \\
\hline Litters, $n^{f}$ & 81 & 84 & 93 & 94 & & & \\
\hline Litter weight after cross-fostering, $\mathrm{kg}^{\mathrm{g}}$ & 17.21 & 17.10 & 19.40 & 19.29 & 0.287 & 0.687 & $<0.001$ \\
\hline Litter weight on day $21, \mathrm{~kg}$ & 62.0 & 60.7 & 69.6 & 69.9 & 1.304 & 0.699 & $<0.001$ \\
\hline Litter gain, kg & 45.3 & 43.6 & 50.2 & 50.7 & 1.253 & 0.622 & $<0.001$ \\
\hline Pigs weaned per litter & 10.79 & 10.76 & 10.78 & 10.72 & 0.100 & 0.687 & 0.816 \\
\hline Piglet mortality, \% & 10.10 & 10.27 & 10.14 & 10.62 & 0.837 & 0.704 & 0.816 \\
\hline No-value pigs, $\%^{\mathrm{h}}$ & 6.12 & 5.17 & 3.85 & 4.40 & 0.997 & 0.829 & 0.104 \\
\hline
\end{tabular}

${ }^{a}$ Values represent least squares means of $n$ sows. This Experiment was conducted from February to June

${ }^{\mathrm{b}}$ The statistical analysis tested for main effects of betaine supplementation, parity group and their interactions. Group of placement (1 to 28 ) was used as the random effect. No significant interactions were detected $(P \geq 0.21)$

'Sow body weight (BW) was measured prior to entering the farrowing room (112 \pm 2 day of gestation)

${ }^{\mathrm{d}}$ Sow BW after farrowing was calculated using equations of Walker and Young [20]

eSow gain:feed was calculated as sow BW gain or loss plus total litter gain divided by total feed intake during lactation

${ }^{\mathrm{f}} \mathrm{A}$ subset of 352 sows was used to measure litter performance (group 1 to 16). Data were collected from February to April

${ }^{\mathrm{g}}$ Litters were standardized to 12 pigs per litter

${ }^{\mathrm{h}} \mathrm{No}$ value pigs consisted of pigs weighing less than $3.62 \mathrm{~kg}$ at day 21 of lactation

Supplementation of betaine during lactation in the summer experiment reduced feed intake, but the reduction in feed intake was not observed in the non-summer study. It should be noted that feed intake of sows during the non-summer experiment was greater than that of sows during the summer experiment, thus betaine intake was actually greater for sows in the non-summer experiment and may have contributed to differences between experiments. Reduction in feed intake in lactating sows has been observed when natural betaine was added at $0.2 \%$ [9] and at $0.4 \%$ [12]. However, Cabezón et al. [11] reported an increase in feed intake when $0.3 \%$ of betaine hydrochloride ( $70.7 \%$ betaine) was added to diets of lactating sows, specifically in parity 2 sows. In another study, Cabezón et al. [22] reported increased feed intake in parity 1 and 2 sows when betaine was supplemented at $0.3 \%$ as betaine hydrochloride, but feed intake was not affected by betaine in parity 3 to 5 or parity $6+$ sows. In a metaanalysis, Sales [23] reported a mean effect side (Hedges's g) of -0.155 (95\% confidence interval was -0.352 to 0.043 ) indicating a negative association of feed intake and betaine supplementation in finishing pigs; however, data showed a substantial amount of heterogeneity, indicating that responses between studies were highly variable. In the present studies, betaine supplementation during lactation did not affect litter performance, regardless of the season. These results are in agreement with Campbell and Virtanen [12] who did not observe an improvement in litter gain due to dietary betaine. Nonetheless, Ramis et al. [9] and Greiner et al. [10] reported an improvement in litter gain and no differences in the number of pigs weaned when betaine was supplemented.

Interestingly, sows weaned in the non-summer presented signs of estrus 0.8 days later than sows weaned in the summer months. Supplementation of betaine during lactation consistently reduced weaning to estrus interval [9-11]. In the summer experiment, betaine supplementation during lactation did not impact the number of days to estrus, however, betaine supplementation post-weaning reduced days to estrus. In the non-summer experiment, betaine supplementation during lactation reduced the number of days to estrus; however, betaine supplementation post-weaning did not affect days to estrus.

In both experiments, supplementation of betaine during the post-weaning period reduced farrowing rate. There is no prior research available on the impacts of feeding 
Table 8 Effect of betaine supplementation on subsequent reproductive performance of sows during non-summer months (Exp. 2) ${ }^{c}$

\begin{tabular}{|c|c|c|c|c|c|c|c|c|c|c|c|c|}
\hline \multirow[t]{5}{*}{ Item } & \multicolumn{4}{|c|}{ Parity 1 and 2} & \multicolumn{4}{|c|}{ Parity $3+$} & \multirow[t]{5}{*}{ SEM } & \multirow{2}{*}{\multicolumn{3}{|c|}{$P$-values ${ }^{d}$}} \\
\hline & \multicolumn{8}{|c|}{ Betaine in lactation diets, $\%$} & & & & \\
\hline & 0 & 0 & 0.2 & 0.2 & 0 & 0 & 0.2 & 0.2 & & \multirow{3}{*}{$\begin{array}{l}\text { Parity } \\
\text { group }\end{array}$} & \multirow{3}{*}{$\begin{array}{l}\text { Betaine } \\
\text { lactation }\end{array}$} & \multirow{3}{*}{$\begin{array}{l}\text { Betaine } \\
\text { post- } \\
\text { weaning }\end{array}$} \\
\hline & \multicolumn{8}{|c|}{ Betaine in post-weaning diets, $\%$} & & & & \\
\hline & 0 & 0.2 & 0 & 0.2 & 0 & 0.2 & 0 & 0.2 & & & & \\
\hline Sows, $n$ & 77 & 73 & 74 & 76 & 81 & 82 & 83 & 81 & & & & \\
\hline Days to estrus ${ }^{\mathrm{e}}$ & $6.67^{a, b}$ & $8.19^{\mathrm{a}}$ & $6.83^{a, b}$ & $5.76^{\mathrm{b}}$ & $8.21^{\mathrm{a}}$ & $6.93^{\mathrm{a}, \mathrm{b}}$ & $7.26^{a, b}$ & $6.70^{\mathrm{a}, \mathrm{b}}$ & 0.752 & 0.401 & 0.077 & 0.473 \\
\hline Bred within 7 days:weaned & 0.792 & 0.740 & 0.811 & 0.803 & 0.679 & 0.780 & 0.735 & 0.765 & 0.048 & 0.172 & 0.370 & 0.601 \\
\hline Bred within 14 days:weaned & 0.831 & 0.753 & 0.838 & 0.829 & 0.778 & 0.817 & 0.855 & 0.790 & 0.044 & 0.930 & 0.290 & 0.369 \\
\hline Overall bred:weaned ${ }^{f}$ & 0.987 & 0.918 & 0.973 & 0.921 & 1.000 & 1.000 & 0.988 & 0.963 & 0.019 & 0.005 & 0.268 & 0.008 \\
\hline Returns:bred within 14 days ${ }^{9}$ & 0.109 & 0.109 & 0.081 & 0.095 & 0.143 & 0.119 & 0.239 & 0.219 & 0.044 & 0.008 & 0.214 & 0.809 \\
\hline Farrowed:weaned ${ }^{g, h}$ & 0.870 & 0.822 & 0.865 & 0.803 & 0.963 & 0.915 & 0.831 & 0.802 & 0.039 & 0.169 & 0.015 & 0.089 \\
\hline Cull:weaned' & 0.104 & 0.153 & 0.108 & 0.171 & 0.025 & 0.061 & 0.120 & 0.148 & 0.035 & 0.069 & 0.040 & 0.079 \\
\hline Total born & 12.54 & 12.37 & 13.53 & 12.19 & 14.49 & 13.77 & 14.00 & 13.66 & 0.441 & $<0.001$ & 0.868 & 0.040 \\
\hline Born alive & 12.13 & 11.85 & 12.56 & 11.72 & 13.54 & 12.76 & 13.05 & 12.88 & 0.412 & 0.001 & 0.954 & 0.075 \\
\hline Still born & 0.41 & 0.53 & 0.84 & 0.47 & 0.88 & 0.91 & 0.83 & 0.78 & 0.126 & 0.001 & 0.620 & 0.448 \\
\hline Mummies & 0.222 & 0.132 & 0.143 & 0.158 & 0.305 & 0.214 & 0.322 & 0.138 & 0.064 & 0.073 & 0.536 & 0.054 \\
\hline $\begin{array}{l}\text { a,b } \text { Means with different superscri } \\
{ }^{c} \text { Values represent least squares } \\
{ }^{d} \text { The statistical analysis tested fo } \\
\text { placement ( } 1 \text { to } 28 \text { ) was used as } \\
\text { eThree way interaction ( } P=0.09) \\
{ }^{f} \text { Post-weaning and parity group } \\
\text { g Lactation and parity group inter } \\
{ }^{\mathrm{h}} \text { Sows that were weaned and far } \\
\text { 'Lactation and parity group inter }\end{array}$ & $\begin{array}{l}\text { eraction } \\
\text { tion }(P \\
\text { ved res }\end{array}$ & $\begin{array}{l}=0.07 \\
\text { D5) } \\
\text { less of } \\
\text { 08) }\end{array}$ & . & 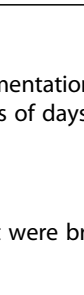 & & 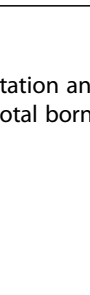 & 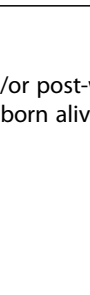 & & . & . & actipn & group of \\
\hline
\end{tabular}

betaine specifically during the post-weaning period until 35 days post-insemination to contrast the findings in the present study. However, a potential cause could be related to the total concentration of betaine present in the diets fed in the post-weaning period. The diets contained $0.489 \%$ and $0.508 \%$ of total betaine for Exp. 1 and 2, respectively. These high levels could have negatively affected sow farrowing rate, although the specific mechanisms underlying this effect are not understood. Campbell and Virtanen [12] reported a reduction in farrowing rate when lactating P1 sows were fed betaine at $0.4 \%$ (83\% farrowing rate), but not when fed $0,0.1 \%$ or $0.2 \%(89 \%, 94 \%$ and $91 \%$ farrowing rate, respectively). In contrast, other studies have not reported a decrease in farrowing rate due to betaine supplementation during lactation [9-11].

The greatest benefit of using betaine in diets of sows has been reported for subsequent litter size. Campbell and Virtanen [12] reported that $\mathrm{P} 2+$ sows had an increased total number of pigs born by 2.3 piglets when betaine was fed, while parity 1 sows did not show an increase. Van Wettere et al. [13] reported an increase in subsequent litter size when betaine ( 7.6 to $9 \mathrm{~g} / \mathrm{d}$ per day) was fed to mature sows during gestation by 1.5 additional piglets. In the current studies, we did not observe an increase in litter size when betaine was supplemented in the non-summer experiment. Nonetheless, in the summer experiment betaine supplementation during lactation to $\mathrm{P} 4+$ sows increased total number of pigs born by 1.2 piglets, but supplementation of betaine in the post-weaning period decreased total number of pigs born by 1.3 piglets.

The mechanism by which betaine may reduce the weaning to estrus interval and increase litter size is not yet fully understood. Supplemental betaine may improve follicular growth in sows as indicated by increased follicular size measured by transrectal ultrasonography [24]. Studies in mice have shown a possible mechanism of betaine increasing embryo development and survival. Transporters of betaine are active during the 2- and 4-cell stage, approximately up to $30 \mathrm{~h}$ after fertilization [25]. During these stages, betaine accumulated in the rodent embryo and potentially served as an osmoprotectant prior to implantation in the initial cellular division and later as a methyl donor in the blastocyst [14]. In addition, betaine serves as a methyl donor, regenerating methionine from homocysteine. High levels of homocysteine have been shown to be associated with pregnancy complications and early pregnancy loss in women [26]. The enzyme betaine-homocysteine methyltransferase was thought to be unique to the liver [27]. Recent studies have shown that this pathway also exists in the blastocyst [15, 28]. Lee et al. [15] found that impaired activity of betaine-homocysteine methyltransferase in the embryo causes embryo reabsorption. 


\section{Conclusions}

No beneficial effects were observed when betaine was supplemented to sows during the non-summer months. Supplementation of betaine during the summer in the lactation period to parity $4+$ sows increased the subsequent litter size. Supplementation of betaine during the summer in the post-weaning period to 35 days post insemination reduced wean-to-estrus interval and increased the total number of pigs born for parity 1 sows. However, feeding betaine in the post-weaning period reduced farrowing rate and reduced the total number of pigs born in parity $4+$ sows. Further research is needed to evaluate supplementation of betaine only during the weaning until breeding period to capture the benefits of reducing wean-to-estrus interval without affecting farrowing rate. In addition, the detrimental effects in feed intake and farrowing rate may be correlated and related to the level of betaine in the diet. Evaluating the optimal level of endogenous and supplemental betaine in the diet of sows will be essential to produce more consistent results.

\section{Acknowledgements}

Acknowledgements are extended to The National Pork Board (Des Moines, IA) for providing partial funding (NPB Project \#13-052). Appreciation is expressed to Marcos Cueva, Heriberto Meza and The Hanor Company Inc., Franklin, KY for their assistance and for providing access to the facilities.

\section{Authors' contributions}

SMM, RDB, JR, PW, and EVH conceptualized and designed the experiment. SMM performed the experiment with the assistance of GEM. SMM analyzed the data. SMM, RDB, and EVH wrote the paper with valuable input from JR, PW, and GEM. All authors reviewed and approved the final manuscript.

\section{Funding}

National Pork Board (Des Moines, IA; NPB Project \#13-052).

\section{Availability of data and materials}

The dataset analyzed in the present study can be made available from the corresponding author upon reasonable request.

\section{Ethics approval}

All animals used in the present studies were humanely treated and the experimental protocol and procedures used followed the practices outlined in the Guide for the Care and Use of Animals in Agricultural Research and Teaching. Protocols were under the supervision of licensed veterinarians.

\section{Consent for publication}

Not applicable.

\section{Competing interests}

The authors declare that they have no competing interests.

\section{Author details}

'Department of Animal Science, North Carolina State University, Raleigh, NC 27695, USA. ${ }^{2}$ The Hanor Company Inc., Franklin, KY 42134, USA. ${ }^{3}$ DuPont Animal Nutrition, Wilmington, DE 19803, USA. ${ }^{4}$ AB Vista, Marlborough, UK.

Received: 23 January 2020 Accepted: 11 May 2020

Published online: 02 July 2020

\section{References}

1. St-Pierre NR, Cobanov B, Schnitkey G. Economic losses from heat stress by US livestock industries. J Dairy Sci. 2003. https://doi.org/10.3168/jds.S00220302(03)74040-5.
2. Hennessy DP, Williamson PE. Stress and summer infertility in pigs. Aust Vet J. 1984. https://doi.org/10.1111/j.1751-0813.1984.tb05991.x.

3. Bloemhof SP, Mathur K, Knol EF, van der Waaij EH. Effect of daily environmental temperature on farrowing rate and total born in dam line sows. J Anim Sci. 2013. https://doi.org/10.2527/jas.2012-5902.

4. Quiniou N, Noblet J. Influence of high ambient temperatures on performance of multiparous lactating sows. J Anim Sci. 1999. https://doi. org/10.2527/1999.7782124x.

5. Spencer JD, Boyd RD, Cabrera R, Allee GL. Early weaning to reduce tissue mobilization in lactating sows and milk supplementation to enhance pig weaning weight during extreme heat stress. J Anim Sci. 2003. https://doi. org/10.2527/2003.8182041x.

6. Black JL, Mullan BP, Lorschy ML, Giles LR. Lactation in the sow during heat stress. Livest Prod Sci. 1993. https://doi.org/10.1016/0301-6226(93)90188-n.

7. Kidd MT, Ferket PR, Garlich JD. Nutritional and osmoregulatory functions of betaine. Worlds Poult Sci J. 1997. https://doi.org/10.1079/WPS19970013.

8. Ashraf M, Foolad MR. Roles of glycine betaine and proline in improving plant abiotic stress resistance. Environ Exp Bot. 2007. https://doi.org/10. 1016/j.envexpbot.2005.12.006.

9. Ramis G, Evangelista JNB, Quereda JJ, Pallares FJ, De Fuente JM, Muñoz A. Use of betaine in gilts and sows during lactation: effects on milk quality, reproductive parameters, and piglet performance. J Swine Health Prod. 2011;19:226-32

10. Greiner L, Remus J, Hall DD, Boyd RD, Harrell RJ, Connor J. The impact of feeding natural betaine to lactation sows during periods of heat stress. J Anim Sci. 2014;92(Suppl. 2):64.

11. Cabezón FA, Schinckel AP, Richert BT, Stewart KR, Gandarillas M, Pasache M, et al. Effect of betaine supplementation during summer on sow lactation and subsequent farrowing performance. Prof Anim Sci. 2016. https://doi. org/10.15232/pas.2016-01532.

12. Campbell $\mathrm{R}$, Virtanen $\mathrm{H}$. Methods of enhancing reproductive performance of animals. U.S.: Patent 6,183,760. filed April 19, 1996; issued February 6; 2001.

13. van Wettere WHEJ, Herde P, Hughes PE. Supplementing sow gestation diets with betaine during summer increases litter size of sows with greater numbers of parities. Anim Reprod Sci. 2012. https://doi.org/10.1016/j. anireprosci.2012.04.007.

14. Corbett HE, Dubé CD, Slow S, Lever M, Trasler JM, Baltz JM. Uptake of betaine into mouse cumulus-oocyte complexes via the SLC7A6 isoform of y+L transporter. Biol Reprod. 2014;90. https://doi.org/10.1095/biolreprod.113. 116939.

15. Lee MB, Kooistra M, Zhang B, Slow S, Fortier AL, Garrow TA, et al. Betaine homocysteine methyltransferase is active in the mouse blastocyst and promotes inner cell mass development. J Biol Chem. 2012. https://doi.org/ 10.1074/jbc.m112.365478.

16. Hague WM. Homocysteine and pregnancy. Best Pract Res Clin Obstet Gynaecol. 2003;17. https://doi.org/10.1016/s1521-6934(03)00009-9.

17. Federation of Animal Science Societies (FASS). Guide for the care and use of agricultural animals in research and teaching. Champaign: FASS; 2010.

18. National Research Council (NRC). Nutrient requirements of swine. 11th ed. Washington DC: National Academy Press; 2012.

19. Association of Official Analytical Chemists (AOAC). Official methods of analysis. 18th ed. Gaithersburg: Association of official analytical chemists; 2005.

20. Walker B, Young BA. Modelling the development of uterine components and sow body composition in response to nutrient intake during pregnancy. Livest Prod Sci. 1992. https://doi.org/10.1016/s03016226(06)80014-x.

21. Chendrimada TP, Neto MG, Pesti GM, Davis AJ, Bakalli RI. Determination of the betaine content of feed ingredients using high-performance liquid chromatography. J Sci Food Agric. 2002. https://doi.org/10.1002/jsfa.1214.

22. Cabezón FA, Schinckel AP, Richert BT, Stewart KR, Gandarillas M, Peralta WA. Analysis of lactation feed intakes for sows including data on environmental temperatures and humidity. Prof Anim Sci. 2016. https://doi.org/10.15232/ pas.2015-01495.

23. Sales J. A meta-analysis of the effects of dietary betaine supplementation on finishing performance and carcass characteristics of pigs. Anim Feed Sci Technol. 2011. https://doi.org/10.1016/j.anifeedsci.2011.02.008.

24. Cabezón FA, Stewart KR, Schinckel AP, Richert BT. Effects of betaine and heat stress on lactation and postweaning reproductive performance of sows. Prof Anim Sci. 2017. https://doi.org/10.15232/pas.2016-01571. 
25. Anas MK, Lee MB, Zhou C, Hammer MA, Slow S, Karmouch J, et al. SIT1 is a betaine/proline transporter that is activated in mouse eggs after fertilization and functions until the 2-cell stage. Development. 2008. https://doi.org/10. 1242/dev.0265z75

26. Holmes VA. Changes in haemostasis during normal pregnancy: does homocysteine play a role in maintaining homeostasis? Proc Nutr Soc. 2003. https://doi.org/10.1079/pns2003251.

27. Finkelstein JD. Methionine metabolism in mammals. J Nutr Biochem. 1990 https://doi.org/10.1016/0955-2863(90)90070-2.

28. Zhang B, Denomme MM, White CR, Leung KY, Lee MB, Greene NDE, et al. Both the folate cycle and betainehomocysteine methyltransferase contribute methyl groups for DNA methylation in mouse blastocysts. FASEB J. 2015. https://doi.org/10.1096/fj.14-261131.

Ready to submit your research? Choose BMC and benefit from:

- fast, convenient online submission

- thorough peer review by experienced researchers in your field

- rapid publication on acceptance

- support for research data, including large and complex data types

- gold Open Access which fosters wider collaboration and increased citations

- maximum visibility for your research: over $100 \mathrm{M}$ website views per year

At BMC, research is always in progress.

Learn more biomedcentral.com/submissions 